\title{
Applying educational theories into planning a psychomotor learning activity: An undergraduate Neonatal Resuscitation Program experience
}

\author{
Erwin J. Khoo, MRCPCH ${ }^{a}$, Siew H. Chua, MRCP ${ }^{b}$ and Stefan Kutzsche, M.D. ${ }^{c}$
}

\begin{abstract}
TheNeonatal Resuscitation Programmeis a good example of an effective educational intervention that has improved perinatal mortality rates in many countries. This paper shares our experience of planning an undergraduate Neonatal Resuscitation Programme using basic principles of education theory of spiral curriculum, Bloom's taxonomy in planning learning outcomes, Kolb's learning model and Miller's model of clinical assessment. Engaging clinicians in pedagogical theories may not be well aligned with how clinicians traditionally thought they learnt best, yet it is key to improving learning concept and educational intervention outcomes in the healthcare professions. This article aims to illustrate the application of such educational theories into one example of practice. We structured this paper in the scope of content, delivery and assessment when planning a psychomotor learning activity.

Keywords: curriculum, learning, medical education, medical schools, pedagogy.
\end{abstract}

http:/ / dx.doi.org/10.5546/aap.2019.eng.e181

a. Department of Pediatrics, International Medical University, Malaysia.

b. Internal Medicine Department, International Medical University, Malaysia.

c. IMU Centre of Education, International Medical University, Malaysia.

E-mail address:

Dr. Erwin Khoo: jiayuan_khoo@imu. edu.my

Funding:

None.

Conflict of interest: None.

Received: 5-22-2018

Accepted: 12-4-2018
To cite: Khoo EJ, Chua SH, Kutzsche S. Applying educational theories into planning a psychomotor learning activity: An undergraduate Neonatal Resuscitation Program experience. Arch Argent Pediatr

The Neonatal Resuscitation Program (NRP) established in 1987 by the American Academy of Paediatrics and American Heart Association was introduced in many countries as a systematic training programme for perinatal health professionals. Today, more than two million health care professional in over 120 countries had been trained in the technique of neonatal resuscitation for the attendance at every delivery. ${ }^{1}$ Because of this educational intervention, many countries reported improvement in perinatal and neonatal mortality rates by the turn of the millennium..$^{2-4}$

However, the NRP targets 2019;117(2):e181-e187. mainly professionals rather than undergraduate students. Given the depth of knowledge and skills needed, it appears unlikely that house officer (a junior doctor) will be competent on the first exposure of the programme. Moreover, teaching of psychomotor skills is known to be challenging in the undergraduate level because of the constraint in time and resources.., 6 We modified the original programme structure to adapt to final year undergraduate medical students in the International Medical University, Malaysia, and aim to introduce NRP to undergraduates as a spiral (learning) process in preparation for the workforce. The challenge is however to design and implement a psychomotor learning activity in the limited time in medical school.

This paper shares our experience in planning the activity using basic principles of education theory. It illustrates how an established educational programme designed for postgraduate professionals can be adapted into undergraduate learning. We structured the paper in the scope of curriculum planning: content, delivery and assessment when planning a psychomotor learning activity.

\section{CONTENT}

\section{Spiral curriculum}

Undergraduate medical students must recognise the need for lifelong learning in medical education. Advances in technology and internet developments resulted in rapid learning experience rendered the years of medical school akin to just the start of a lifelong spiral curriculum. 
FIGURE 1. The planning of introductory Neonatal Resuscitation Program in medical school at the tip of the spiral curriculum

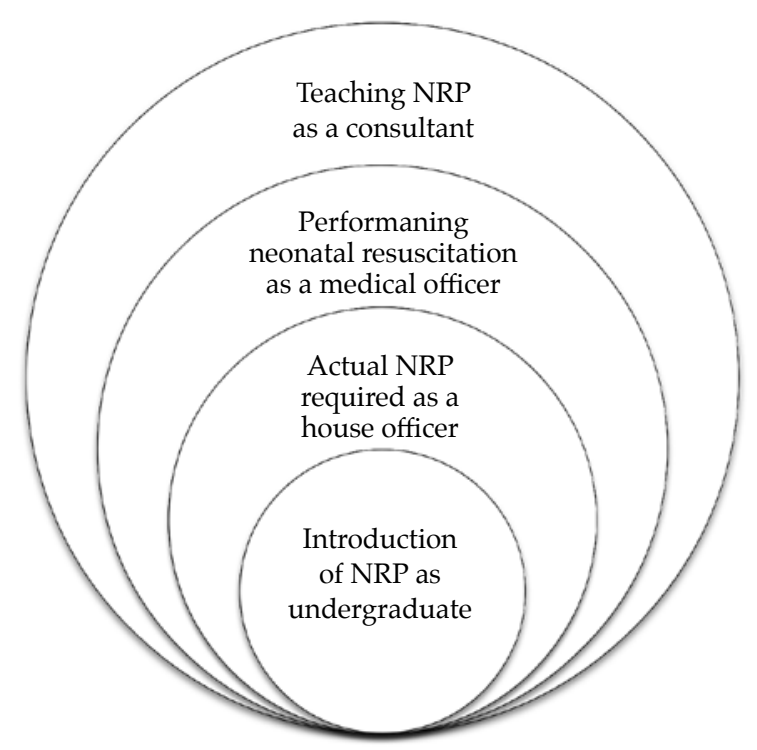

NRP: Neonatal Resuscitation Program.
Spiral curriculum is a concept described by Jerome Bruner ${ }^{7}$ in 1960 where there are repetitive revisiting of topics that requires the deepening of understanding with each new learning relating to the previous one with increasing level of difficulty and competence.

We introduced NRP to our undergraduates in the final year because at that time, experiences accumulated throughout their learning activities in medical school act as an important reservoir of experiences. These pool of clinical skills are an important foundation when introducing a psychomotor learning as it requires coordination of cognitive ability and physical functions. Figure 1 depicts how introducing NRP to undergraduate fits into their life-long career.

The introduction of the NRP in undergraduate level is just the tip of the cone. Once a learner graduate, house officers in Malaysia undergo the actual NRP required of them. The deepening of competency continues when medical officers

TABLE 1. Using Bloom's taxonomy to plan learning outcomes

\begin{tabular}{|c|c|c|}
\hline $\begin{array}{l}\text { Bloom's } \\
\text { taxonomy }\end{array}$ & Definition & $\begin{array}{l}\text { Learning outcome by level of complexity: } \\
\text { By the end of this programme, students } \\
\text { should be able to... }\end{array}$ \\
\hline Remembering & $\begin{array}{l}\text { Retrieving relevant } \\
\text { information from memory. }\end{array}$ & $\begin{array}{l}\text { Recall standard algorithm in newborn } \\
\text { resuscitation scenarios. }\end{array}$ \\
\hline Understanding & $\begin{array}{l}\text { Determining the meaning } \\
\text { of instructional ideas. }\end{array}$ & $\begin{array}{l}\text { Interpret and classify different emergency } \\
\text { scenarios presented in the newborn. }\end{array}$ \\
\hline Applying & $\begin{array}{l}\text { Carrying out practical } \\
\text { solutions given in a } \\
\text { situation. }\end{array}$ & $\begin{array}{l}\text { Execute and demonstrate airway protection } \\
\text { and ventilation, chest compression, and } \\
\text { administration of emergency drugs. }\end{array}$ \\
\hline Analysing & $\begin{array}{l}\text { Breaking scenarios into } \\
\text { parts and detecting how it } \\
\text { relates one to another. }\end{array}$ & $\begin{array}{l}\text { Differentiate the cause of unsuccessful } \\
\text { resuscitation. }\end{array}$ \\
\hline Evaluating & $\begin{array}{l}\text { Making judgements } \\
\text { based on performance. }\end{array}$ & Critique and appraise learning activities. \\
\hline Creating & $\begin{array}{l}\text { Putting elements together } \\
\text { to form an original } \\
\text { scenario. }\end{array}$ & $\begin{array}{l}\text { Reflect and produce sets of different } \\
\text { scenarios where students play the role of } \\
\text { teachers. }\end{array}$ \\
\hline
\end{tabular}


resuscitate a new born in actual emergencies as a competent trainee. Thus, prior exposure to NRP attempt to facilitate retention of knowledge when such information is reinforced in the standard programme introduced later.

\section{Outcome based education}

After understanding the relevance of introducing a psychomotor learning activity into an undergraduate programme, the next task for the teachers is to develop the expected learning outcome of the activity that are appropriate to learners. This concept of outcome based education (OBE) was promoted by Spady ${ }^{8}$ in 1994 as a performance-based approach in medical education. Outcomes expected at the end of the programme is required to be clearly stated in the planning stages. When a learner graduates from each spiral step, the learning outcomes at subsequent learning curve would be different.

The learning outcomes define the process of what is thought. This is important when there are a diverse teaching faculty across a department. It helps when faculty becomes unavailable by assisting the replacement faculty to achieve the outcome expected without changing the curriculum. Although the outcomes had been specified, the means to achieve the outcomes are fairly open. Different student's (or teacher's) abilities and learning (or teaching) styles can be accommodated throughout this learning (and teaching) process.

Understanding Bloom's taxonomy is the root in planning learning outcomes. In 1956, Bloom' ${ }^{9}$ classifies thinking behaviors into level of complexity through a hierarchal model that were believed to be important learning processes. It was later revised by Anderson et al., ${ }^{10}$ in 2001 using verbs to describe the taxonomy (Table 1). Table 2 imparts our experience of writing the learning outcomes in a S.M.A.R.T (Specific, Measurable, Attainable, Results focused, Tailored and time appropriate) objectives where it was first coined by George Doran ${ }^{11}$ in 1981 when writing management goals and objectives.

However, OBE is not without its criticism. ${ }^{12}$ It is perceived as limitations being placed in a vast field of medicine and its rigid model was said to transform teachers into 'education technician'. OBE also fails to address creativity which is an important domain in advancement of healthcare. Medicine changes quickly - what we learnt in medical school a decade ago, might be obsolete in the next.

TABLE 2. Learning outcomes written as S.M.A.R.T. objectives

\begin{tabular}{|l|l|l|}
\hline S & Specific & The outcomes are detailed explicitly in the student's posting guide. \\
\hline M & Measurable & $\begin{array}{l}\text { A pre/post (educational) intervention theory assessment and a } \\
\text { standard NRP Skills Performance Checklist are able to measure } \\
\text { student's outcomes. }\end{array}$ \\
\hline A & Attainable & The outcomes are achievable given the student's educational \\
experience in an undergraduate level.
\end{tabular}


Yet, OBE allows learners to understand what is expected of them and makes it possible for learners to create their own learning agenda. They could reflect on the content and make better sense of it at their own pace. Care and avoidance of rigidity is needed where OBE is implemented. The ultimate goal is to improve the student's learning. ${ }^{13}$

\section{Delivery}

STEPS technique and Kolb's learning model

A useful approach in structuring a psychomotor learning activity is via the STEPS technique (setting the foundation, Teacher demonstration, Explanation, Practice, Subsequent personalised practice).$^{14}$ In 1976, David Kolb ${ }^{15}$ developed the experiential learning model stating that effective learning elements is seen

TABLE 3. Utilising STEPS technique to teach technical skills of positive pressure ventilation matching the Kolb's experiential learning model

\begin{tabular}{|c|c|c|c|c|}
\hline $\begin{array}{c}\text { STEPS } \\
\text { technique }\end{array}$ & $\begin{array}{l}\text { Kolb's experiential } \\
\text { learning cycle }\end{array}$ & \multirow{2}{*}{\multicolumn{3}{|c|}{ Student's learning styles }} \\
\hline \multicolumn{2}{|c|}{$\begin{array}{l}\text { Setting the foundation. The teacher } \\
\text { explains the learning outcomes and the } \\
\text { relevance of the skills. }\end{array}$} & & & \\
\hline $\begin{array}{l}\text { Teacher } \\
\text { demonstrates } \\
\text { PPV without } \\
\text { explanation }\end{array}$ & $\begin{array}{l}\text { Concrete experience } \\
\text { where there is encounter } \\
\text { of a new experience of } \\
\text { PPV in newborns. }\end{array}$ & \multirow{2}{*}{$\begin{array}{l}\text { Perceiving } \\
\text { information: } \\
\text { Individuals } \\
\text { prefer } \\
\text { watching / } \\
\text { listening } \\
\text { than doing. }\end{array}$} & & \\
\hline $\begin{array}{c}\text { Explanation of } \\
\text { effective PPV } \\
\text { with } \\
\text { demonstration }\end{array}$ & $\begin{array}{l}\text { Reflective observation } \\
\text { where one reflects on the } \\
\text { new encountered } \\
\text { experience. }\end{array}$ & & $\begin{array}{l}\text { Individuals } \\
\text { prefer good } \\
\text { clear } \\
\text { information }\end{array}$ & \\
\hline $\begin{array}{c}\text { Learner's } \\
\text { practise PPV } \\
\text { under } \\
\text { supervision with } \\
\text { feedback }\end{array}$ & $\begin{array}{l}\text { Abstract } \\
\text { conceptualization takes } \\
\text { place where new ideas } \\
\text { are formed based on the } \\
\text { reflection. }\end{array}$ & & $\begin{array}{l}\text { logically } \\
\text { reflect on } \\
\text { the } \\
\text { information } \\
\text { given. }\end{array}$ & $\begin{array}{l}\text { Processing } \\
\text { information: } \\
\text { Individuals } \\
\text { prefer } \\
\text { solving } \\
\text { problem and }\end{array}$ \\
\hline $\begin{array}{c}\text { Learner's } \\
\text { subsequent } \\
\text { personalised } \\
\text { practise }\end{array}$ & $\begin{array}{l}\text { Active experimentation } \\
\text { stage is where learners } \\
\text { apply the new ideas to } \\
\text { their surroundings to } \\
\text { appreciate if there are } \\
\text { any modifications in the } \\
\text { next appearance of the } \\
\text { experience (Table } 5 \text { ). }\end{array}$ & & & $\begin{array}{l}\text { putting their } \\
\text { learning into } \\
\text { practice. }\end{array}$ \\
\hline
\end{tabular}

PPV: positive pressure ventilation. 
when a learner progresses through a cycle of four stages: of (1) having a concrete experience, followed by (2) reflective observation on that experience, which leads to (3) the formation of abstract concepts where new ideas are formed, which are then (4) actively experiment for future situations, resulting in new experiences. Table 3 shows an example of how we matched the STEPS technique with Kolb's model when teaching positive pressure ventilation (PPV).

\section{Simulation based medical education}

Simulation based medical education (SBME) is defined as an educational activity that utilises simulation tools or methods to create new experiences of learning opportunities. SBME has advantage of providing feedback and active learning to students and promoting the use of decision making skills in an environment similar to a clinical setting while emphasising on patient safety and safeguarding patients' best interest. ${ }^{6,16}$ In 2009, Peter Dieckmann, ${ }^{17}$ described the elements of a SBME using an eight-phase model. (Table 4) We applied this approach in the learner's 'active experimentation' stage i.e. the final bit of Kolb's learning cycle.

TABLE 4. Eight phases of Simulation Based Medical Education described by Dieckmann et al.

\begin{tabular}{|c|c|}
\hline $\begin{array}{l}\text { 1. Setting the } \\
\text { introduction }\end{array}$ & $\begin{array}{l}\text { Teachers are responsible to set up the simulation as actual as possible } \\
\text { (creating a realistic environment, using as much actual equipment as } \\
\text { possible, and designing scenarios that students could imagine). There } \\
\text { must be an agreement for teacher and students to 'suspend disbelief' } \\
\text { and do their best as if everything is real. }\end{array}$ \\
\hline $\begin{array}{l}\text { 2. Simulator } \\
\text { briefing }\end{array}$ & Familiarisation with the simulator, equipment and the environment \\
\hline $\begin{array}{l}\text { 3. Theory } \\
\text { input }\end{array}$ & Presentation of learning outcomes \\
\hline $\begin{array}{l}\text { 4. Scenario } \\
\text { briefings }\end{array}$ & $\begin{array}{l}\text { For example, students are given details about the scenario that involve a } \\
\text { birthing mother without complication, and a newborn who requires } \\
\text { assessment and intervention. }\end{array}$ \\
\hline $\begin{array}{l}\text { 5. Simulation } \\
\text { and } \\
\text { ending }\end{array}$ & $\begin{array}{l}\text { Teachers conclude the scenario with an unbiased statement e.g. 'The } \\
\text { scenario ends here. Let's debrief now' with no judgement made on } \\
\text { student's performance during simulation. }\end{array}$ \\
\hline $\begin{array}{l}\text { 6. Debriefing } \\
\text { and } \\
\text { feedback }\end{array}$ & $\begin{array}{l}\text { The debriefing is where actual learning takes place. The undergraduate } \\
\text { NRP started off with a positive comment that reinforced good behaviour } \\
\text { and building up of competency while establishing a constructive and } \\
\text { safe atmosphere. Learners who made 'mistakes' were given opportunity } \\
\text { to express on how they would have performed if given another try. The } \\
\text { most valued learning is where student's realised their 'mistakes'. An } \\
\text { effective debrief often questions students (rather than commenting on } \\
\text { them). Use strategies such as 'tell me about what happen when there } \\
\text { were no chest rise on PPV', 'what caused the disagreement', or 'what } \\
\text { did you learn when the saturation did not picked up after you attempt } \\
\text { PPV'. }\end{array}$ \\
\hline \multicolumn{2}{|l|}{ 7. Breaks } \\
\hline $\begin{array}{l}\text { 8. Course } \\
\text { ending }\end{array}$ & f the course and preparation of learning plans \\
\hline
\end{tabular}

NRP: Neonatal Resuscitation Program.

PPV: positive pressure ventilation. 


\section{Assessment}

When planning assessments, it is important to be aware of the purpose of the assessment and where it fits into the learners' learning curve. In 1990, George Miller's ${ }^{18}$ 'pyramid' illustrated the framework of different facets of clinical assessment. (Figure 2) We asked ourselves, are we assessing undergraduate's knowledge, competence, performance or action? At the minimum and at the tip of the spiral learning, students must know what is required in order to perform neonatal resuscitation. In an undergraduate level, this knowledge base would be the pillar of their assessment. To fulfil the broader objective in their career later, learners must then know how to use the knowledge they have accumulated. It is this quality of being functionally adequate that defines competence later as a healthcare professional but not yet from an undergraduate. Performing and teaching neonatal resuscitation are skills illustrated further up the pyramid.

All methods of assessment have its own strengths and weaknesses. ${ }^{19}$ Formative and summative assessments are the two most common types of assessment in medical school. While formative assessment monitors and provides student's with feedback as learning, summative assessment evaluates student's learning at the end of the programme by comparing it against a benchmark. Our assessment emphasised on 'assessment for learning' (formative) rather than 'assessment of learning' (summative).

In view of time constraint in the already crowded undergraduate's curriculum, we set a theoretical formative assessment by using a set of questions through pre- and post-test. The pretest is a set of questions given to learners before

FigURE 2. Miller's framework for clinical assessment

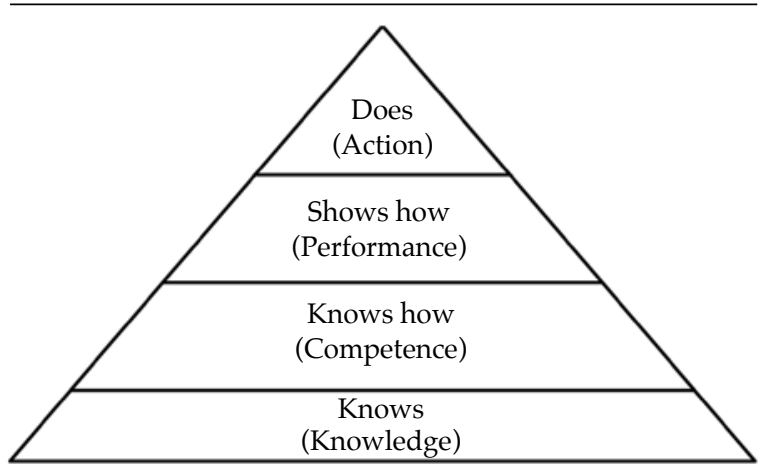

the educational intervention followed by post-test where students answer the same set of questions. While pre- and post-tests are traditionally used to measure knowledge gained after the intervention, we used them to engage learners to learn. This model of feedback supports and improves learning by motivating students 'to learn, not study'. Using simple paired $t$-test statistical analysis on the convenience sampling of our pilot cohort of 28 students when the activity was first introduced, pre- and post-test mean score was $44.3(\mathrm{SD}+11.2)$ and $61.6(\mathrm{SD}+12.8)$ respectively. There was a significant score increment of $+17.3 \%$ (SD + 9.2, $95 \%$ CI 13.8 to 20.9$)(\mathrm{p}<0.001)$. This methodology used here is transferable to teachers wishing to take up the challenge to test the efficacy of an educational intervention.

\section{Limitations}

We noted several limitations from this experience. First, one can argue of the need in using 'practical' assessment tool for a psychomotor learning activity rather than a 'written' assessment. Furthermore, 'written' assessment is a poor predictor of skills performance in resuscitation. ${ }^{20}$ However, using simulation assessment requires active trainer involvement and low learner-to-trainer ratios. This comes with hidden costs and faculty time. To avoid burnout and successfully sustain implementation of this psychomotor learning activity, undergraduate curriculum activities need to be creative in building, sustaining, and managing the trainer workforce. ${ }^{21}$ Our experience showed that this psychomotor learning activity is feasible, cost effective and transferable to what was expected at an undergraduate level. Secondly, the education principles applied are general and not specific to the undergraduate NRP. It was unclear to what extend the knowledge acquired was translated into actual retention after graduation. Next, we were also unable to perform meaningful sample size estimation because there has not been a commonly accepted definition on what constitutes an educationally important learning gain in terms of neonatal resuscitation skills. ${ }^{22}$

\section{CONCLUSIONS}

This paper of basic educational principles has presented a practical framework which programme and course coordinator can use in the planning of educational psychomotor skills activities in undergraduate medical school. As 
the need for skill activities is well recognized, the challenge is to make it effective, sustainable and cost-effective in undergraduate programmes. Despite this, there is still a wide chasm to be bridged between a simulated model that produces pre-programmed feedback to learners, and a real patient who will flail and scream.

In an educational institution, it is vital to plan undergraduate curriculum to imbue learners the sense of lifelong learning and mature 'adultness' education. There are papers adapting NRP to undergraduates, but the challenge is still to gauge its effectiveness. ${ }^{22-25}$ We showed that it is simple to use basic principles of education theory in planning such activity for undergraduates. Further studies should be conducted by following graduates having applied such experience.

\section{REFERENCES}

1. American Academy of Pediatrics. Neonatal Resuscitation Program - Home. [Accessed on: April 17, 2018]. Available at: https: / / www.aap.org/en-us/ continuing-medicaleducation/life-support/NRP/Pages/History.aspx

2. Boo NY. Neonatal resuscitation programme in Malaysia: an eight-year experience. Singapore Med J. 2009; 50(2):152-9.

3. Finkelstein JZ, Duhau M, Speranza A. Trend in infant mortality rate in Argentina within the framework of the Millennium Development Goals. Arch Argent Pediatr. 2016; 114(3):216-22.

4. Patel A, Khatib MN, Kurhe K, Bhargava S, et al. Impact of neonatal resuscitation trainings on neonatal and perinatal mortality: a systematic review and meta-analysis. BMJ Paediatr Open. 2017; 1(1):e000183.

5. Vogel D, Harendza S. Basic practical skills teaching and learning in undergraduate medical education-a review on methodological evidence. GMS J Med Educ. 2016; 33(4):Doc64.

6. Clerihew L, Rowney D, Ker J. Simulation in paediatric training. Arch Dis Child Educ Pract Ed. 2016; 101(1):8-14.

7. Bruner JS. The Process of Education. Cambridge, MA: Harvard University Press 1960.

8. Spady WG. Outcome-Based Education: Critical Issues and Answers. Arlington, Va: American Association of School Administrators; 1994.

9. Bloom BS. Taxonomy of educational objectives: The classification of educational goals. New York: Longman; 1956.
10. Anderson LW, Krathwohl DR (eds). A taxonomy for learning, teaching, and assessing: A revision of Bloom's taxonomy of educational objectives. Boston: Allyn \& Bacon; 2001.

11. Doran GT. There's a S.M.A.R.T. way to write management's goals and objectives. Management Rev. 1981; 70(11):35-6.

12. Touchie $C$, ten Cate $O$. The promise, perils, problems and progress of competency $\square$ based medical education. Med Educ. 2016; 50(1):93-100.

13. Tam M. Outcomes-based approach to quality assessment and curriculum improvement in higher education. Quality Assurance in Education. 2014; 22(2):158-68.

14. Ker JS. Clinical Skills Centre Teaching. In Dent J, Harden R (eds). A Practical Guide for Medical Teachers. 4th ed. London: Churchill Livingstone-Elsevier; 2013.Pag.79.

15. Kolb DA. Learning styles inventory. Boston: Hay Group, Hay Resources Direct; 1976.

16. Khoo EJ, Schremmer RD, Diekema DS, Lantos JD. Ethical Concerns When Minors Act as Standardized Patients. Pediatrics. 2017; 139(3):e20162795.

17. DieckmannP, DieckmannP.Simulation settings forlearning in acute medical care. In Using Simulations for Education, Training and Research. Lengerich: Pabst; 2009: 40-138.

18. Miller GE. The assessment of clinical skills/competence/ performance. Acad Med. 1990; 65(9 Suppl):S63-7.

19. Epstein RM. Assessment in medical education. $N$ Engl J Med. 2007; 356(4):387-96.

20. Rodgers DL, Bhanji F, McKee BR. Written evaluation is not a predictor for skills performance in an Advanced Cardiovascular Life Support Course. Resuscitation. 2010;81(4):453-6.

21. Acton RD, Chipman JG, Lunden M, Schmitz CC. Unanticipated teaching demands rise with simulation training: strategies for managing faculty workload. J Surg Educ. 2015; 72(3):522-9.

22. Lai NM, Ngim CF, Fullerton PD. Teaching medical students neonatal resuscitation: knowledge gained and retained from a brief simulation-based training workshop. Educ Health (Abingdon). 2012; 25(2):105-10.

23. Chimhuya S, Mbuwayesango B, Aagaard EM, Nathoo KJ. Development of a neonatal curriculum for medical students in Zimbabwe-a cross sectional survey. BMC Med Educ. 2018; 18(1):90.

24. Kudreviciene A, Nadisauskiene RJ, Tameliene R, Tamelis $A$, et al. Initial neonatal resuscitation: skill retention after the implementation of the novel $24 / 7$ HybridLab® learning system. J Matern Fetal Neonatal Med. 2017; 22:1-8.

25. Nimbalkar A, Patel D, Kungwani A, Phatak A, et al. Randomized control trial of high fidelity vs low fidelity simulation for training undergraduate students in neonatal resuscitation. BMC Res Notes. 2015; 8:636. 